\title{
Effect of urea on gas and effluent losses, microbial populations, aerobic stability and chemical composition of corn (Zea mays L.) silage
}

\author{
Efecto de la urea en las pérdidas por gases y efluentes, poblaciones \\ microbianas, estabilidad eróbica y composición química en el ensilaje \\ de maíz (Zea mays L.)
}

Ana Paula Maia dos Santos ${ }^{1}$, Edson Mauro Santos ${ }^{1}$, Juliana Silva de Oliveira ${ }^{1}$, Gleidson Giordano Pinto de Carvalho ${ }^{2}$, Gherman Garcia Leal de Araújo ${ }^{3}$, Anderson Moura Zanine ${ }^{4 *}$, Ricardo Martins Araújo Pinho ${ }^{4}$, Daniele de Jesus Ferreira ${ }^{4}$, Alberto Jefferson da Silva Macedo ${ }^{1}$, Joyce Pereira Alves ${ }^{1}$

Originales: Recepción: 14/05/2019 - Aceptación: 16/07/2020

\begin{abstract}
We evaluated the effects of urea addition on gas and effluent losses, fermentation profile, microbial populations, aerobic stability and chemical composition of corn silages. A completely randomised design with five levels of urea $(0,0.5,1.0,1.5$, and $2.0 \%$ based on dry matter) and five replicates was used. A decreasing linear effect of urea levels on effluent losses in corn silages was observed. In parallel, an increasing linear effect of urea levels on pH, increasing from 3.49 to 4.12 in silages without urea in relation to silages with the maximum urea level, was also observed. Urea addition improved the aerobic stability of the silages, with $62 \mathrm{~h}$ for the silages without urea and from 90 to $>96 \mathrm{~h}$ for the silages with urea. Based on the results of the principal components, two groups (I and II) could be distinguished. The most discriminating variables in group I were dry matter $(-0.9), \mathrm{pH}$ $(-1.2)$ and lactic acid bacteria (-0.9), while in group II, effluent losses (1.0), ethanol (1.0), acetic acid (0.8) and gas losses (0.8) were most important. The use of urea at inclusion levels of around $2 \%$ in corn silage reduced gas losses, improved the nutritive value and promote the aerobic stability of silages.
\end{abstract}

Keywords

lactic acid • lactic acid bacteria $\bullet$ silage additives $\bullet$ yeasts $\bullet$ Zea mays L.

1 Federal University of Paraíba. Department of Animal Science. Rod. Pb-079, 58397 000. Areia. Paraíba. Brazil.

2 Federal University of Bahia. Department of Animal Science. Av. Adhemar de Barros. 500. Ondina. 40170110. Salvador. Bahia. Brazil.

3 Brazilian Agricultural Research Corporation. Embrapa Tropical Semiarid. Rodovia BR-428. Km 152. S/N, 56302970. Petrolina. Pernambuco. Brazil.

4 Federal University of Maranhão. Department of Animal Science. Rodovia BR 222. km 4, s/n. 65500-000. Chapadinha. Maranhão. Brazil. * anderson.zanine@ibest.com.br 


\section{RESUMEN}

El objetivo del presente estudio fue evaluar el efecto de la urea en las pérdidas por gases y efluentes, poblaciones microbianas, estabilidad aeróbica y composición química en el ensilaje de maíz. Se utilizó un diseño completamente al azar con cinco niveles de urea $(0,0,5,1,0,1,5$ y $2,0 \%$ basado en materia seca) y cinco repeticiones. Hubo un efecto lineal decreciente de los niveles de urea en las pérdidas de efluentes en los ensilajes de maíz y en los valores de pH que aumentaron de 3,49 a 4,12 en los ensilajes sin urea en relación con los ensilajes con el nivel máximo de urea. Los ensilajes de urea mejoraron la estabilidad aeróbica de los ensilajes en comparación con aquellos sin la adición de urea, siendo $62 \mathrm{~h}$ para los ensilajes sin urea y de 90 a $>96$ h para los ensilajes con urea. El análisis de componentes principales permitió formar dos grupos (I y II). Las variables más discriminatorias en el grupo I fueron: materia seca $(-0,9), \mathrm{pH}(-1,2)$ y bacterias del ácido láctico $(-0,9)$; mientras que en el grupo II: pérdidas de efluentes $(1,0)$, etanol $(1,0)$, ácido acético $(0,8)$ y pérdidas de gas $(0,8)$. El uso de urea a niveles cercanos al $2 \%$ en ensilaje de maíz reduce las pérdidas de gas, mejora el valor nutritivo y promueve una mayor estabilidad aeróbica de los ensilajes.

Palabras clave

ácido láctico $\bullet$ bacterias de ácido láctico $\bullet$ aditivos de ensilaje $\bullet$ levaduras $\bullet$ Zea mays $\mathrm{L}$.

\section{INTRODUCTION}

Ensiling is a preservation technique for moist forage based on anaerobic fermentation, in which lactic acid bacteria metabolise soluble sugars into organic acids, especially lactic acid. Thus, the biomass becomes acidified, and the forage is preserved until the silo is opened $(9,13,25)$.

Among the forage species most suitable for silage production, corn (Zea mays L.) is highlighted due to its high nutritive value, adequate dry matter content, high concentration of fermentable carbohydrates, low buffering power and high digestibility. However, the high concentration of water-soluble carbohydrates of many cultivars $(10,13,20)$ may produce excess of lactic acid and predispose the ensiled mass to the development of yeasts, especially during aerobic exposure throughout the feeding phase (27). According to Pahlow et al. (2003), corn plants may have 3 to 5 log colony-forming unit (CFU)/g of yeasts, which may compromise the aerobic stability of the silage $(4,25)$, reducing its nutritive value (29) and precluding animal performance (6).

Yeasts are the initiating microorganisms of the aerobic deterioration of silages due to lactate assimilation (13). Aerobic instability is associated with molds and yeasts in corn silages, occurring mainly in the upper layers of the silage, which are more prone to deterioration $(4,10)$. To minimise this effect, additives with antifungal properties are used to reduce yeast populations and increase aerobic stability in silage $(4,25)$. Previous studies have focused on the reduction of losses during ensiling and after opening the silo, using chemical additives $(16,27)$. Urea, used as chemical additive, in silages can be converted into ammonia since it undergoes hydrolysis in the presence of moisture and under urease activity (enzyme catalyst) of plants and microorganisms, producing two molecules of ammonia and carbon dioxide (13). Thus, the addition of urea would provide temporary buffering of the ensiled mass, slightly increasing the $\mathrm{pH}$ values and mildly reducing the lactic acid content as a function of the heterofermentative lactic acid bacteria in the initial fermentation stage (17). This would result in silage less prone to aerobic deterioration.

Besides reducing aerobic instability, silages ensiled with non-protein nitrogen can show high contents of protein in the silage, meeting ruminant requirements (6).

In this way, the use of urea as a chemical additive in corn silages with a high concentration of water-soluble carbohydrates in experimentally defined proportions can reduce fermentative losses and the toxic effect to the population of yeasts and moulds, improving the nutritional value of silages.

In this respect, the aim was to evaluate the effect of urea on losses by gases and effluents, microbial populations, aerobic stability and chemical composition in corn silage. 


\section{MATERIALS AND METHODS}

\section{Experimental area and climatic conditions}

The experiment was carried out in the Forage Farming Sector of the Department of Animal Science of the Center of Agricultural Sciences, Federal University of Paraíba - UFPB, located in the mesoregion of Agreste and the microregion of Brejo Paraibano, municipality of Areia, at the coordinates of $06^{\circ} 57^{\prime} 46^{\prime \prime} \mathrm{S}$ and $35^{\circ} 41^{\prime} 31^{\prime \prime} \mathrm{W}$ and an elevation of $623 \mathrm{~m}$ above sea level. The climate in the region, according to the Köppen classification, is As' (hot and humid), with an average annual rainfall of $1,400 \mathrm{~mm}$, an average annual temperature of $24.5^{\circ} \mathrm{C}$ and an average relative humidity of $80 \%$.

\section{Experimental design and treatments}

Corn harvesting was carried out at an age of 97 days, when the grains were in the milky/pasty stage. Whole plants were manually harvested and chopped to a length of $2 \mathrm{~cm}$ with a stationary forage machine. Chopped corn was divided into $10-\mathrm{kg}$ piles, and each pile was assigned to one of the following urea levels: 0, 0.5, 1.0, 1.5 and 2.0\%, based on dry matter. All treatments were dissolved in $50 \mathrm{~mL}$ of deionised water and sprayed on the forages uniformly and under constant mixing.

The material was packed into five polyvinyl chloride (PVC) experimental silos, with a length of $300 \mathrm{~mm}$ and a diameter of $150 \mathrm{~mm}$, to achieve a final packing density of $600 \pm 20 \mathrm{~kg}$ of fresh matter $/ \mathrm{m}^{3}$. The PVC silos were equipped with a Bunsen's valve to allow gas exit and $1.5 \mathrm{~kg}$ of sand at the bottom (for effluent drainage). Subsequently, the silos were sealed, weighed and stored for $70 \mathrm{~d}$ in a covered area at ambient temperature $\left(25 \pm 2^{\circ} \mathrm{C}\right)$.

\section{Dry matter losses}

The silos were weighed on the silage day and after 70 days of the fermentation process to estimate fermentation losses. To estimate gases, effluent losses and dry matter recovery, the equations described by Zanine et al. (2010) were used.

\section{Chemical analysis and aerobic stability}

Before ensiling, one entire corn plant was sampled to estimate its chemical composition and microbial populations prior to ensiling (table 1).

Table 1. Chemical composition and microbial populations of a fresh whole corn plant before ensiling.

NDFap - Neutral detergent fibre corrected for ash and protein; CFU -Colonyforming unit. NDFap - fibra detergente neutral corregida por cenizas y proteínas; Unidad de entrenamiento de colonia de CFU.
Tabla 1. Composición química y poblaciones microbianas de toda la planta de maíz antes del ensilaje.

\begin{tabular}{|l|r|}
\hline Dry matter $\left(\mathrm{g} \mathrm{kg}^{-1}\right)$ & 262.49 \\
\hline Crude protein $\left(\mathrm{g} \mathrm{kg}^{-1} \mathrm{DM}\right)$ & 62.05 \\
\hline Mineral matter $\left(\mathrm{g} \mathrm{kg}^{-1} \mathrm{DM}\right)$ & 32.34 \\
\hline $\mathrm{NDFap}^{1}\left(\mathrm{~g} \mathrm{~kg}^{-1} \mathrm{MS}\right)$ & 548.34 \\
\hline Total soluble carbohydrates $\left(\mathrm{g} \mathrm{kg}^{-1} \mathrm{DM}\right)$ & 152.14 \\
\hline Lactic acid bacteria $(\log \mathrm{cfu} / \mathrm{g})^{2}$ & 5.50 \\
\hline Yeasts and moulds $(\log \mathrm{cfu} / \mathrm{g})$ & 4.30 \\
\hline
\end{tabular}

The $\mathrm{pH}$ was determined in distilled water in duplicate, using a potentiometer. Briefly, approximately $25 \mathrm{~g}$ of the ensiled material from each treatment were mixed with $100 \mathrm{~mL}$ of water. After $1 \mathrm{~h}$, reading was performed according to the methodology described by Bolsen et al. (1992).

A fraction of $10 \mathrm{ml}$ was collected from these solutions, rediluted with $1 \mathrm{~mL}$ of distilled water, acidified with $50 \% \mathrm{H}_{2} \mathrm{SO}_{4}$ and filtered through Whatman filter paper for organic acid and ethanol analysis (10).

Subsequently, $2 \mathrm{ml}$ of the filtrate were spiked with $1 \mathrm{~mL}$ of $20 \%$ metaphosphoric acid and $0.2 \mathrm{~mL}$ of $0.1 \%$ phenolic acid. The samples were centrifuged, and organic acids (lactic acid, acetic, propionic and butyric) and ethanol were analysed by high-performance liquid chromatography (HPLC), using a SHIMADZU, model SPD detector-10 VP coupled to an ultraviolet (UV) detector at a wavelength of $210 \mathrm{~nm}$. 
Microbiological evaluation was performed according to Kung and Ranjit (2001); 25-g fresh silage samples, extracted according to the defined opening periods, were collected. Subsequently, we added $225 \mathrm{~mL}$ of sterile Ringer's solution and blended the mixture for approximately $1 \mathrm{~min}$, followed by the removal of $1 \mathrm{~mL}$ and appropriate dilution $\left(10^{-1}\right.$ to $\left.10^{-9}\right)$. Plating was performed in duplicate for each culture medium. In addition, the microbial populations of the forages and silages were analysed; LAB were enumerated in triplicate by pour-plating using the de Man, Rogosa and Sharpe MRS agar. Agar plates were incubated anaerobically for $48 \mathrm{~h}$ at $39^{\circ} \mathrm{C}$, and yeasts and moulds (Y\&M) were enumerated in triplicate by pour-plating with potato dextrose agar and anaerobic incubation for 7 days at room temperature. Enterobacteria were determined on violet-red bile and anaerobically incubated for $24 \mathrm{~h}$ at $35^{\circ} \mathrm{C}$. Plates from the appropriate dilutions were counted when they contained a minimum of 30 and a maximum of 300 colonies. For data analysis, the counts were transformed into $\log 10 \mathrm{cfu} / \mathrm{g}$.

Chemical analyses were performed at the Laboratory of Animal Nutrition and Food Evaluation of the CCA/UFPB. The samples were conditioned in paper bags, weighed and kept in an oven at $60^{\circ} \mathrm{C}$ for $48 \mathrm{~h}$. Afterwards, they were milled in a Willey type mill with a 1-mm mesh sieve and subjected to analyses.

We analysed dry matter (DM -method no. 934.01), ash (method no. 930.05) and crude protein (CP-method no.981·10) according to the methodologies of the AOAC (1990). Neutral detergent fibre was corrected for ash and protein (NDFap) according to Licitra et al. (1996) and Mertens (2002).

Water-soluble carbohydrate (WSC) values were determined via spectrophotometry according to the method described by Dubois et al. (1956). For extraction, $100 \mathrm{mg}$ of dry and milled sample were added to $100 \mathrm{~mL}$ of $80 \%$ ethanol solution and placed in a water bath at $80^{\circ} \mathrm{C}$ for $30 \mathrm{~min}$. Subsequently, the material was filtered, the solid residue discarded, the volume was completed to $500 \mathrm{~mL}$ with distilled water in a volumetric flask and the ethanolic extract was homogenised. We then added $1 \mathrm{~mL}$ of $5 \%$ phenol solution and $5 \mathrm{~mL}$ of concentrated sulfuric acid and removed 2-mL aliquots of ethanolic extract. A standard curve was constructed with increasing $0.01 \%$ glucose solution concentrations, and the spectrophotometer readings were conducted at $490 \mathrm{~nm}$ absorbance. The WSC contents were calculated in $\mathrm{g} \times 100 \mathrm{~mL}^{-1}$ based on the solution and then fitted according to the dry matter of each sample.

Corn silage aerobic stability was determined through samples of approximately $2 \pm 0.03 \mathrm{~kg}$ silage from each silo. The samples were relocated in silos cleaned without compaction, and the internal temperature of the silage mass was verified every $1 \mathrm{~h}$ using a digital immersion thermometer. The ambient temperature was recorded through a thermometer suspended in the air. Aerobic stability was calculated as the number of hours before the silage mass temperature reached $2^{\circ} \mathrm{C}$ above room temperature (25).

\section{Statistical analysis}

The data were analysed using the PROC GLM of the SAS 8.2 Software and subjected to analysis of variance and regression (21). The criterion adopted for choosing the regression models was the significance of parameters estimated by the models and the values of the coefficients of determination; P-values less than 0.05 were considered significant.

The significance levels of Pearson's correlation coefficients were estimated for fermentation, microbiological losses and losses of corn silage.

Principal components analysis allows grouping the largest amount of original information contained in p variables $(P=13$, in the present study) into a coordinate system covered by two principal components ( 1 and 2) (7), allowing to plot the variables in a two-dimensional graph. The multivariate analysis was processed using STATISTICA version 7.0 (23), and the graph was generated via the MVSP tool, trial version 3.2. 


\section{RESULTS}

\section{Dry matter losses}

The addition of urea to corn silage did not significantly affect $(P>0.05)$ dry matter recovery (table 2 ).

Table 2. Dry matter losses of corn silages treated with urea.

${ }^{1}$ SEM - Standard error mean; ${ }^{2}$ Lin - linear; ${ }^{3}$ Quad - Quadratic; ${ }^{4} \mathrm{DMR}$ Dry Matter Recovery. ${ }^{1}$ SEM

- Error estándar medio; ${ }^{2}$ Lin - lineal; ${ }^{3}$ Quad - Cuadrático; ${ }^{4}$ DMR - Recuperación de materia seca.
${ }^{1}$ SEM - Standard error mean; ${ }^{2}$ Lin - linear; ${ }^{3}$ Quad - Quadratic.

${ }^{1}$ SEM - Error estándar medio; ${ }^{2}$ Lin - lineal; ${ }^{3}$ Quad - Cuadrático.
Tabla 2. Pérdidas de materia seca de ensilajes de maíz tratados con urea.

\begin{tabular}{|c|c|c|c|c|c|c|c|c|}
\hline \multirow{2}{*}{ Item } & \multicolumn{5}{|c|}{ Urea (\% of DM) } & \multirow{2}{*}{ SEM $^{1}$} & \multicolumn{2}{|c|}{ P-value } \\
\hline & 0.0 & 0.5 & 1.0 & 1.5 & 2.0 & & $\operatorname{Lin}^{2}$ & Quad $^{3}$ \\
\hline Gas losses ( $\left.\mathrm{g} \mathrm{kg}^{-1} \mathrm{DM}\right)$ & 26.7 & 29.2 & 21.2 & 27.0 & 23.0 & 1.69 & 0.4940 & 0.0121 \\
\hline Effluent losses (kg/ton) & 160.0 & 154.0 & 109.0 & 108.0 & 109.0 & 0.55 & $<0.001$ & 0.0060 \\
\hline $\mathrm{DMR}^{4}\left(\mathrm{~g} \mathrm{~kg}^{-1} \mathrm{DM}\right)$ & 946.1 & 951.0 & 961.4 & 951.0 & 948.6 & 1.55 & 0.1895 & 0.0972 \\
\hline
\end{tabular}

However, there was a decreasing linear effect $(P<0.001)$ of urea levels on effluent losses in corn silages, with a reduction from 160.0 to $109.0 \mathrm{~kg} / \mathrm{t}$ in silages without urea in relation to silages with the maximum level of urea (2.0\%), with an estimated reduction of $29.6 \mathrm{~kg} / \mathrm{t}$ for every $1 \%$ of urea added to the ensiled mass. The gas losses presented a positive quadratic effect $(P=0.0121)$ with regression estimated a maximum point of gas losses close to $0.52 \%$ to inclusion of urea.

\section{Fermentation profile and microbial populations of the silages}

There was an increasing linear effect of urea level $(P<0.05)$ on $\mathrm{pH}$ values in corn silages, increasing from 3.49 to 4.12 in silages without urea in relation to silages with the maximum urea level (table 3).

Table 3. Fermentative profile and microbial populations of corn silages treated with urea. Tabla 3. Perfil de fermentación y poblaciones microbianas de ensilajes de maíz tratados con urea.

\begin{tabular}{|c|c|c|c|c|c|c|c|c|}
\hline \multirow{2}{*}{ Item } & \multicolumn{5}{|c|}{ Urea (\% of DM) } & \multirow{2}{*}{ SEM $^{1}$} & \multicolumn{2}{|c|}{ P-value } \\
\hline & 0 & 0.5 & 1.0 & 1.5 & 2.0 & & $\operatorname{Lin}^{2}$ & Quad $^{3}$ \\
\hline $\mathrm{pH}$ & 3.49 & 3.50 & 4.08 & 4.06 & 4.12 & 0.035 & $<0.001$ & 0.1689 \\
\hline Lactic acid ( $\left.\mathrm{g} \mathrm{kg}^{-1} \mathrm{DM}\right)$ & 46.62 & 45.79 & 47.55 & 38.41 & 55.83 & 0.608 & 0.8010 & 0.1001 \\
\hline Acetic acid $\left(\mathrm{g} \mathrm{kg}^{-1} \mathrm{DM}\right)$ & 28.50 & 15.91 & 21.38 & 11.53 & 18.90 & 0.206 & 0.4506 & 0.7220 \\
\hline Propionic acid $\left(\mathrm{g} \mathrm{kg}^{-1} \mathrm{DM}\right)$ & 0.66 & 0.41 & 0.49 & 0.37 & 0.42 & 0.008 & 0.4770 & 0.1384 \\
\hline Butyric acid ( $\left.\mathrm{g} \mathrm{kg}^{-1} \mathrm{DM}\right)$ & 0.39 & 0.38 & 0.38 & 0.33 & 0.29 & 0.006 & 0.0131 & 0.1026 \\
\hline Ethanol $\left(\mathrm{g} \mathrm{kg}^{-1} \mathrm{DM}\right)$ & 21.95 & 12.63 & 5.75 & 6.01 & 7.85 & 0.566 & 0.2303 & 0.1107 \\
\hline Lactic acid bacteria ${ }^{7}(\log \mathrm{cfu} / \mathrm{g})$ & 7.52 & 8.01 & 9.01 & 9.04 & 8.58 & 0.028 & 0.1400 & 0.0004 \\
\hline Yeasts and moulds (log cfu/g) & 4.86 & 5.01 & 3.95 & 4.25 & 4.00 & 0.013 & 0.3050 & 0.2261 \\
\hline
\end{tabular}

Lactic, acetic and propionic acids did not significantly influence the corn silages $(P>0.05)$. However, the butyric acid concentrations of the silages showed a linear decreasing effect $(P=0.0131)$. There was a quadratic fitting for the concentrations of populations of lactic bacteria $(P<0.001)$ (table 3$)$, with the maximum point of LAB populations close to a urea inclusion level of $1.5 \%$.

Average lactic acid concentration was $44.59 \mathrm{~g} / \mathrm{kg} \mathrm{DM}$, showing that the addition of urea maintained the lactic acid contents in the corn silages $(P=0.1001)$ (table 3$)$. A similar behaviour was found for acetic acid concentrations $(P=0.4506)$, which showed an average content of $19.24 \mathrm{~g} / \mathrm{kg} \mathrm{DM}$ in corn silages. The urea levels did not alter $(P=0.1384)$ the concentrations of propionic acid in the silages, averaging $0.47 \mathrm{~g} / \mathrm{kg} \mathrm{DM}$. The highest concentration of butyric acid $(P=0.0131)$ was observed in silage without urea $(0.39 \mathrm{~g} / \mathrm{kg} \mathrm{DM})$ and the lowest concentration of butyric acid in silage with the highest level of urea $(0.29 \mathrm{~g} / \mathrm{kg} \mathrm{DM})$ (table 3$)$. 
Ethanol concentrations did not affect corn silage $(P>0.05)$. For populations of lactic acid bacteria of the silages, the addition level of $1.5 \%$ urea resulted in $9.04 \mathrm{log} \mathrm{cfu} / \mathrm{g}$ in the forage $(P<0.001)$ (table 3, page 313).

\section{Chemical composition}

The addition of urea did not significantly influence the dry matter content $(P=0.0522)$ of the silages, averaging close to $28 \%$. There was, however, a linear effect on ash concentrations $(\mathrm{P}<0.001)$ (table 4).

The crude protein content of corn silages increased linearly $(P<0.001)$, and there was a linear decrease $(P=0.0150)$ for the concentrations of NDFap in corn silages (table 4$)$.

${ }^{1}$ SEM - Standard error mean; ${ }^{2}$ Lin - linear; ${ }^{3}$ Quad Quadratic; ${ }^{4}$ DM - Dry matter on a fresh matter basis; ${ }^{5} \mathrm{CP}$ - Crude protein; ${ }^{6}$ NDFap neutral detergent fibre corrected for ash and protein; ${ }^{7}$ WSC - watersoluble carbohydrates.

${ }^{1}$ SEM - Error estándar medio; ${ }^{2}$ Lin - lineal; ${ }^{3}$ Quad - Cuadrático;

${ }^{4} \mathrm{DM}$ - Materia seca; ${ }^{5} \mathrm{CP}$ - proteína cruda; ${ }^{6}$ NDFap - fibra detergente neutral corregida para cenizas y proteínas; ${ }^{7}$ WSC carbohidratos solubles en agua.

${ }^{1}$ SEM - Standard error mean; ${ }^{2} \mathrm{Lin}$ - linear; ${ }^{3}$ Quad Quadratic.

${ }^{1}$ SEM - Error estándar medio; ${ }^{2}$ Lin - lineal; ${ }^{3}$ Quad - Cuadrático.
Table 4. Chemical composition of corn silage treated with urea.

Tabla 4. Composición química de ensilajes de maíz tratados con urea.

\begin{tabular}{|c|c|c|c|c|c|c|c|c|}
\hline \multirow{2}{*}{ Item } & \multicolumn{5}{|c|}{ Urea (\% DM) } & \multirow{2}{*}{ SEM $^{1}$} & \multicolumn{2}{|c|}{ P-value } \\
\hline & 0 & 0.5 & 1.0 & 1.5 & 2.0 & & $\operatorname{Lin}^{2}$ & Quad $^{3}$ \\
\hline $\mathrm{DM}^{4}\left(\mathrm{~g} \mathrm{~kg}^{-1}\right)$ & 270.80 & 311.20 & 282.46 & 296.06 & 224.93 & 1.925 & 0.5273 & 0.0522 \\
\hline Ash $\left(\mathrm{g} \mathrm{kg}^{-1} \mathrm{DM}\right)$ & 33.37 & 33.79 & 37.86 & 39.99 & 50.53 & 1.256 & $<0.001$ & 0.3893 \\
\hline $\mathrm{CP}^{5}\left(\mathrm{~g} \mathrm{~kg}^{-1} \mathrm{DM}\right)$ & 82.15 & 108.98 & 111.51 & 139.93 & 143.18 & 2.574 & $<0.001$ & 0.0017 \\
\hline $\mathrm{NDFap}^{6}\left(\mathrm{~g} \mathrm{~kg}^{-1} \mathrm{DM}\right)$ & 494.80 & 502.72 & 475.12 & 444.45 & 420.60 & 7.666 & 0.0150 & 0.9514 \\
\hline $\mathrm{WSC}^{7}\left(\mathrm{~g} \mathrm{~kg}^{-1} \mathrm{DM}\right)$ & 80.42 & 75.72 & 87.19 & 103.32 & 72.54 & 1.569 & 0.2170 & 0.2600 \\
\hline
\end{tabular}

There was no significant effect of the urea levels in the silages on the water-soluble carbohydrate concentrations $(P=0.2170)$, with average values of $84.89 \mathrm{~g} / \mathrm{kg}$.

\section{Aerobic stability of silages}

The maximum temperature showed a linear decrease $(P=0.0010)$ after exposure to air during the 96-h period. The $\mathrm{pH}$ values of corn silages after exposure to air during the 96-h period were not affected $(P=0.1406)$, (table 5$)$.

The yeast populations recorded in the corn silages after exposure to air decreased linearly $(P<0.001)$. The average values of yeasts at $96 \mathrm{~h}$ were higher in the silages without urea (table 5).

Table 5. Aerobic stability, $\mathrm{pH}$ and yeast populations of corn silages treated with urea.

Tabla 5. Estabilidad aeróbica, pH y poblaciones de levaduras de ensilajes de maíz tratados con urea.

\begin{tabular}{|c|c|c|c|c|c|c|c|c|}
\hline & \multicolumn{5}{|c|}{ Urea (\% DM) } & \multirow{2}{*}{ SEM $^{1}$} & \multicolumn{2}{|c|}{ P-value } \\
\hline & 0.0 & 0.5 & 1.0 & 1.5 & 2.0 & & $\operatorname{Lin}^{2}$ & Quad $^{3}$ \\
\hline Maximum temperature $\left({ }^{\circ} \mathrm{C}\right)$ & 26.40 & 25.10 & 25.0 & 24.5 & 24.10 & 0.110 & 0.0010 & 0.12005 \\
\hline Aerobic stability (h) & 62 & 90 & $>96$ & $>96$ & $>96$ & 0.365 & - & - \\
\hline \multicolumn{9}{|c|}{ After $96 \mathrm{~h}$ of air exposure } \\
\hline $\mathrm{pH}$ & 4.12 & 4.49 & 4.24 & 4.22 & 4.65 & 0.072 & 0.3024 & 0.1406 \\
\hline Yeasts and moulds (log cfu/g) & 9.69 & 8.10 & 7.92 & 7.12 & 6.84 & 0.209 & $<0.001$ & 0.1070 \\
\hline
\end{tabular}

Urea addition improved the aerobic stability of the silages in relation to those without the addition of urea, being $62 \mathrm{~h}$ for the silages without urea and from 90 to $>96 \mathrm{~h}$ for the silages with urea.

Pearson's correlation coefficient and principal components analysis of fermentative characteristics of silages

Gas losses correlated positively with organic acid concentrations (especially butyric acid). Populations of lactic acid bacteria showed a positive correlation with $\mathrm{pH}$ (figure 1, page 315). 


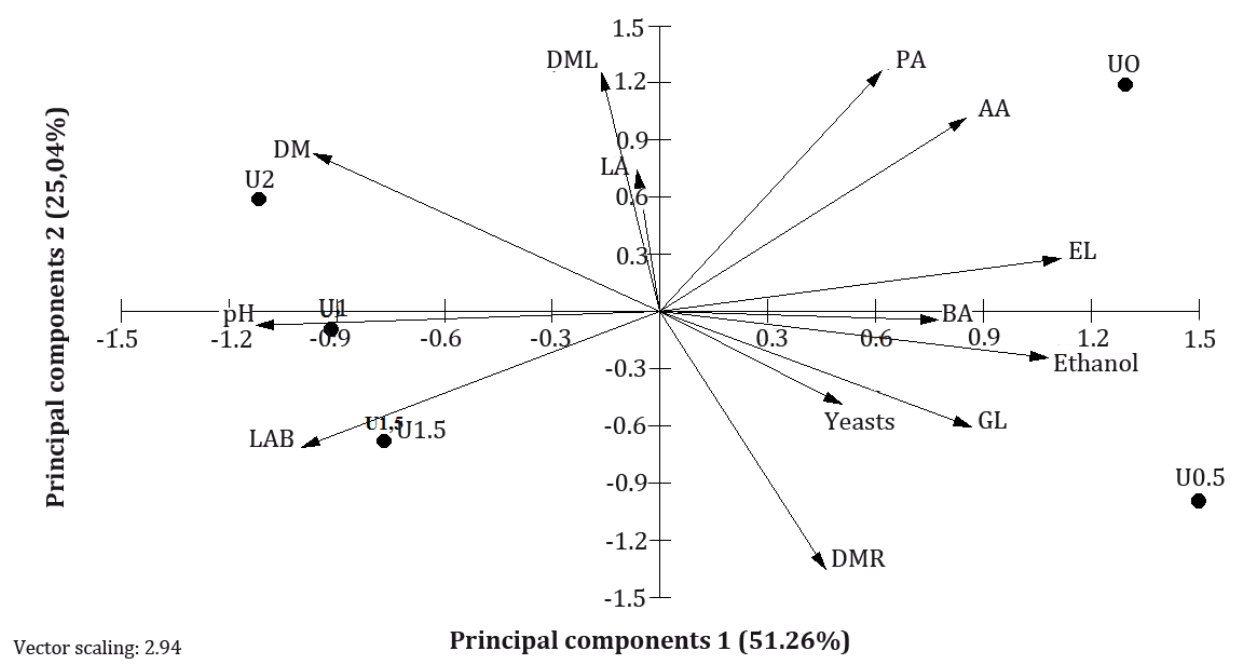

Figure 1. Distribution of dry matter (DM), pH, lactic acid (LA), acetic acid (AA), propionic acid (PA), butyric acid (BA), ethanol, lactic acid bacteria (LAB), yeasts and moulds (Y\&M), dry matter losses (DML), gas losses (GL), effluent losses (EL) and dry matter recovery

(DMR) in the coordinate system covered by principal components 1 and 2 .

Figura 1. Distribución de materia seca (DM), pH, ácido láctico (LA), ácido acético (AA), ácido propiónico (PA), ácido butírico (BA), etanol, bacterias del ácido láctico (LAB), levaduras y mohos (L\&B), pérdidas de materia seca (DML), pérdidas de gas (GL), pérdidas de efluentes (EL) y recuperación de materia seca (DMR) en el sistema de coordenadas cubierto por los componentes principales 1 y 2 .

There was a positive correlation between the concentrations of acetic and propionic acids, which in turn had a strong positive correlation with dry matter losses. The ethanol content of the silages was positively correlated with the acetic, butyric and propionic acid contents and strongly correlated with effluent losses and yeast populations (table 6).

Table 6. Pearson's correlation coefficient of the fermentative profile, microbial populations and dry matter losses of corn silages treated with urea.

Tabla 6. Coeficiente de correlación de Pearson del perfil fermentativo, poblaciones microbianas y pérdidas de materia seca de ensilajes de maíz tratados con urea.

\begin{tabular}{|c|c|c|c|c|c|c|c|c|c|c|c|c|}
\hline & BA $^{1}$ & LA $^{2}$ & $\mathbf{A A}^{3}$ & $\mathbf{P A}^{4}$ & ET $^{5}$ & DM $^{6}$ & GL $^{7}$ & EL $^{8}$ & DMR $^{9}$ & pH & LAB $^{10}$ & $Y \& M^{11}$ \\
\hline $\mathrm{BA}^{1}$ & & -0.174 & 0.442 & 0.557 & 0.510 & -0.659 & 0.597 & 0.583 & -0.072 & -0.363 & -0.432 & -0.141 \\
\hline $\mathrm{LA}^{2}$ & & & 0.156 & 0.156 & 0.110 & -0.359 & 0.328 & -0.004 & 0.156 & -0.083 & -0.203 & -0.432 \\
\hline $\mathrm{AA}^{3}$ & & & & 0.850 & 0.667 & -0.526 & 0.291 & 0.827 & -0.085 & -0.769 & -0.944 & 0.008 \\
\hline $\mathrm{PA}^{4}$ & & & & & 0.332 & -0.585 & 0.367 & 0.623 & 0.307 & -0.480 & -0.723 & -0.154 \\
\hline $\mathrm{ET}^{5}$ & & & & & & -0.410 & 0.264 & 0.909 & 0.276 & -0.842 & -0.803 & 0.403 \\
\hline $\mathrm{DM}^{6}$ & & & & & & & -0.738 & -0.136 & -0.120 & 0.065 & 0.327 & 0.256 \\
\hline $\mathrm{GL}^{7}$ & & & & & & & & 0.210 & -0.093 & -0.253 & -0.128 & -0.274 \\
\hline $\mathrm{EL}^{8}$ & & & & & & & & & 0.043 & -0.834 & -0.918 & 0.347 \\
\hline DMR $^{9}$ & & & & & & & & & & -0.122 & 0.005 & 0.504 \\
\hline $\mathrm{pH}$ & & & & & & & & & & & 0.873 & -0.413 \\
\hline $\mathrm{LAB}^{10}$ & & & & & & & & & & & & -0.299 \\
\hline $\mathrm{Y}^{\prime} \mathrm{M}^{11}$ & & & & & & & & & & & & \\
\hline
\end{tabular}

${ }^{1} \mathrm{BA}$ - butyric acid; ${ }^{2} \mathrm{LA}$ - lactic acid; ${ }^{3} \mathrm{AA}$ - acetic acid; ${ }^{4} \mathrm{PA}$ - propionic acid; ${ }^{5} \mathrm{ET}$ - ethanol; ${ }^{6} \mathrm{DM}$ - dry matter; ${ }^{7} \mathrm{GL}$ - gas losses; ${ }^{8} \mathrm{EL}$ - effluent losses; ${ }^{9} \mathrm{DMR}$ - dry matter recovery; ${ }^{10} \mathrm{LAB}$ - lactic acid bacteria; ${ }^{11} \mathrm{Y} \& \mathrm{M}$ - yeasts and moulds.

${ }^{1} \mathrm{BA}$ - ácido butírico; ${ }^{2} \mathrm{LA}$ - ácido láctico; ${ }^{3} \mathrm{AA}$ - ácido acético; ${ }^{4} \mathrm{PA}$ - ácido propiónico; ${ }^{5} \mathrm{ET}$ - etanol; ${ }^{6} \mathrm{DM}$ - materia seca; ${ }^{7} \mathrm{GL}$ - pérdidas de gas;

${ }^{8} \mathrm{EL}$ - pérdidas de efluentes; ${ }^{9} \mathrm{DMR}$ - recuperación de materia seca; ${ }^{10} \mathrm{LAB}$ - bacterias del ácido láctico; ${ }^{11} \mathrm{Y} \& \mathrm{M}$ - levaduras y mohos. 
Principal components analysis allowed the formation of two groups (I and II). The most discriminating variables in group I were as follows: dry matter $(-0.9), \mathrm{pH}(-1.2)$, and lactic acid bacteria (-0.9), while in group II, they were effluent losses (1.0), ethanol (1.0), acetic acid (0.8) and gas losses (0.8).

Group I, including silages with 1.00, 1.50 and 2.00\% urea, determined by the variables $\mathrm{pH}$, dry matter and lactic acid bacterial populations, can be characterised as silages with the main fermentative product (lactic acid) even at higher $\mathrm{pH}$ values. Additionally, silage with urea showed a negative correlation with variables such as gas losses, effluent losses and ethanol production.

\section{Discussion}

The addition of urea to corn silage increased the $\mathrm{pH}$ values by the ammonia released in the hydrolysis of urea, forming a weak base, ammonium hydroxide $\left(\mathrm{NH}_{4} \mathrm{OH}\right)$ (17). According to McDonald et al. (1991), the $\mathrm{pH}$ of silage should range from 3.8 - 4.2 to benefit the fermentation process; at pH levels below 3.8, yeast development is facilitated. However, acetic acid and urea may inhibit these microorganisms.

Even with the addition from 1 to $2 \%$ urea, the $\mathrm{pH}$ of the experimental silages was within the range verified by Weinberg et al. (2011), in contrast to the findings of Pinto et al. (2012), who verified higher pH values (3.95) in corn silages amended with urea, despite the differences between the values reported in this study. The authors verified that the use of urea in corn silage did not negatively affect the $\mathrm{pH}$ value. These lower $\mathrm{pH}$ values demonstrate that hybrids with high sugar contents are, in fact, prone to excessive acidification, making the addition of buffering additives, such as urea, a necessity.

The microbial ecosystem of corn silages is generally dominated by homofermentativelactic acid bacteria, especially Lactobacillus plantarum (McDonald et al., 1991; Pahlow et al., 2002), suggesting that the buffering allowed proliferation of heterofermentative lactic acid bacteria in a larger or smaller scale by altering the fermentative profile of silages Storm et al. (2010).

The lactic acid concentrations of silages in the present study were similar to those recorded by Pinto et al. (2012), who observed concentrations of $44.30 \mathrm{~g} / \mathrm{kg} \mathrm{DM}$ of lactic acid in corn silages. The high concentrations of acetic acid in the present study may be associated with higher activities of heterofermentative lactic acid bacteria. However, it is also possible that a significant production of acetic acid occurred in the initial period of the fermentation process when there was still oxygen in the silo. In an experiment with silages, Li et al. (2011) identified species of acetic bacteria in corn silages, mainly in the initial phase of the fermentation process. These acid-tolerant microorganisms convert ethanol to acetic acid under aerobic conditions and are generally associated with aerobic silage deterioration (22).

Considering the acidic $\mathrm{pH}$ values of all silages studied, a reduced concentration of butyric acid was expected, since the microorganisms producing this acid were developed in media with a pH close to 6.0. Thus, the low concentration of butyric acid, especially at the highest urea inclusion level, indicates that the addition of urea did not block a desirable fermentation profile of corn silages (3).

According to McDonald et al. (1991) and Pahlow et al. (2002), the number of lactic bacteria required for a significant reduction in $\mathrm{pH}$ of silage is about $8.0 \mathrm{log} \mathrm{cfu} / \mathrm{g}$. However, in the present study with the addition of urea, we observed higher numbers. Urea benefited the development of lactic acid bacteria in the silages by maintaining greater $\mathrm{pH}$ levels when compared to the silages with urea, besides decreasing the ethanol concentration due to the reduction of yeasts.

The reduction of yeast populations in silages treated with urea may be due to the conversion of urea to ammonia in the ensiled mass, facilitating fermentation (15). Urea is an antifungal substance and impedes the metabolism of yeasts, which are auxotrophic microorganisms and strictly depend on the availability of a specific combination between carbon sources and nitrogen sources (26).

In some studies, the authors observed a decrease in yeast populations when urea was applied to forage silage (27). Urea is a poor source of nitrogen for yeasts, which prefer other nitrogen sources (26). Thus, the addition of urea to silage increases the ammonia 
concentration in the ensiled mass, delaying the development of yeasts since it unbalances the specific relationship of substrates for yeast growth. Moreover, according to Hess et al. (2006), high ammonia concentrations are toxic to yeasts, forcing them to modify the nitrogen metabolism, incorporating ammonium in the formation and excretion of amino acids, such as glutamine or glutamate, in the presence of adequate potassium concentrations.

The contents of dry matter in corn silages are adequate to the fermentation process with low effluent production, thus benefiting nutrient availability to the animal (13). When evaluating the effects of additives on corn silage, Pinto et al. (2012) found values of $35.24 \%$ DM for urea-added silages. This difference might be due to the harvest period of corn; in their study, corn was in a more advanced physiological stage.

The increase in crude protein in corn silages treated with urea occurred because urea increases the nitrogen compounds of the silages, suggesting partial incorporation of the nitrogen applied (15). Thus, the beneficial effect of the addition of urea to corn silage, besides reducing gas and effluent losses and leading to dry matter recovery due to the improved fermentation profile in the silage, can also be an increase in feed protein value; the increase in urea nitrogen fractions may also benefit rumen fermentation and promote greater synthesis of microbial proteins (15). In the present study, the silages met the protein requirements of the animals, with silage protein contents above $7.0 \%$.

The addition of urea to corn silages resulted in a reduction of the concentrations of NDFap, most likely because urea acted on the fibrous fraction of the corn silage via ureolysis reactions (15), consisting of an enzymatic reaction in which ammonia is released through urea hydrolysis and of ammonolysis between the ammonia and the ester bonds among hemicellulose chains and between the carbohydrate groups or carbohydrate and lignin molecules, resulting in amide formation. Moreover, ammonia shows high affinity with water, thus forming a weak base, ammonium hydroxide $\left(\mathrm{NH}_{4} \mathrm{OH}\right)$. The high affinity of ammonia with water promotes cell wall expansion and rupture of the fibrous tissue components of the forage ensiled with urea (16).

The degradation of lactic acid in aerobic silages, resulting from the action of acid-tolerant aerobic microorganisms $(4,11)$, increases the $\mathrm{pH}$ of the silages. In the present study, the $\mathrm{pH}$ value obtained with a urea inclusion level of $1.5 \%$ was ideal (13).

The smaller yeast population at $96 \mathrm{~h}$ in corn silages treated with urea may be associated with the ability of urea to increase $\mathrm{pH}$ values of the medium, reducing the potential for the development of yeast populations. On the other hand, the positive effect of urea during oxygen exposure may be associated with the lower yeast population the time of opening, which may have been inhibited by the buffering and antifungal activity of urea during the silage fermentation phase (26). According to McDonald et al. (1991), Spoelstra et al. (1998), Storm et al. (2010) and Pahlow et al. (2002), yeasts are associated with silage deterioration and have a fermentative route (pyruvate decarboxylase acetaldehyde and subsequent reduction of acetaldehyde to ethanol), which causes high losses and can consume up to $48.9 \%$ of dry matter.

The addition of urea reduced the microbial activity and exothermic reactions in the silo after exposure to air (15). Generally, yeasts are the first microorganisms deleterious to silages exposed to air (Da Silva et al., 2010), raising silage temperature and $\mathrm{CO}_{2}$ production (11). However, as urea has a toxic effect on these microorganisms, it is possible that the higher resistance to heating and changes in the silages exposed to air resulted from the addition of urea to corn silage.

Principal components analysis allowed us to generate the two-dimensional biplot formed by the first two principal components. Experimental variables with positive correlations indicate an association of the variable with the samples located to the right on the horizontal axis (CP1), and those with negative correlations indicate an association with the samples located to the left on the horizontal axis (CP1). Thus, the total amount of information of the original variables retained by the two principal components was $76.3 \%$, with $51.26 \%$ for the first principal component and $25.04 \%$ for the second principal component.

Determination of the correlation coefficients of the studied variables allowed us to verify that losses are generally associated with the production of ethanol and butyric acid and with yeast populations. Due to the higher amounts of lactic acid bacterial populations in the silages receiving more than $1.0 \%$ urea, the losses from the fermentation process were 
reduced since the production of lactic acid does not generate quantitative losses because of the lack of $\mathrm{CO}_{2}$ and other undesirable by-products (13).

Group II, consisting of silage without urea or with $0.5 \%$ urea, showed discriminations related to losses and the production of ethanol and acetic acid, indicating that the main fermentation of these silages was probably not only lactic fermentation, generating losses characteristic of the performance of other species of microorganisms, such as yeasts and/or acetic and propionic bacteria.

\section{Conclusions}

The use of urea at levels close to $2 \%$ in corn silage reduces gas losses, improves chemical composition and promotes greater aerobic stability of silages.

\section{REFERENCES}

1.AOAC 1990. Official methods of analysis. $15^{\text {th }}$ ed. Virginia: Association of Official Analytical Chemists.

2. Bolsen, K. K.; Lin, C.; Brent, C. R.; Feverherm, A. M.; Urban, J. E.; Aimutis, W. R. 1992. Effects of silage additives on the microbial succession and fermentation process of alfalfa and corn silages. In Journal of Dairy Science. 75: 3066-3083.

3. Danner, H.; Holzer, M.; Mayrhuber, E.; Braun, R. 2003. Acetic acid increases stability of silage under aerobic conditions. In Applied and Environmental Microbiology. 69: 562-567.

4. Da Silva, T. C.; Smith, M. L.; Barnard, A. M.; Kung Jr., L. 2015. The effect of a chemical additive on the fermentation and aerobic stability of high-moisture corn. In Journal of Dairy Science. 98: $1-12$

5. Dubois, M.; Gilles, K. A.; Hamilton, J. K.; Rebers, P. A.; Smith, F. 1956. Colorimetric method for determination of sugars and related substances. In Analytical Biochemistry. 28: 350-356.

6. Ferreira, D. J.; Zanine, A. M.; Lana, R. P.; Souza, A. L.; Negrão, F. M.; Geron, L. J. V.; Parente, H. N.; Parente, M. O. M. Pinho, R. M. A. 2018. Fermentation and chemical composition of Marandu grass ensiled with dehydrated brewery residue. In Grassland Science. 65: 69-72.

7. Hair, J. F.; Black, W. C.; Babin, B. J.; Anderson, R. E.; Tatham, R. L. 2009. Análise multivariada de dados. Porto Alegre. BRA: Bookman Editora.

8. Hess, D. C.; Lu, W.; Rabinowitz, J. D.; Botstein, D. 2006. Ammonium toxicity and potassium limitation in yeast. In Plos Biology. 4: 2012-2023.

9. Ibarguren, L.; Rebora, C.; Bertona, A.; Antonini, C. 2020. Sorghum silage production in the northern oasis of Mendoza, Argentina. Revista de la Facultad de Ciencias Agrarias. Universidad Nacional de Cuyo. Mendoza. Argentina. 52(1): 121-127.

10. Kung Jr., L.; Ranjit, N. K.2001. The effect of Lactobacillus buchneri and other additives on the fermentation and aerobic stability of barley silage. In Journal of Dairy Science. 84: 1149-1155.

11. Li, Y.; Nishino, N. 2011. Effects of inoculation of Lactobacillus rhamnosus and Lactobacillus buchneri on fermentation, aerobic stability and microbial communities in whole crop corn silage. In Grassland Science, 57: 184-191.

12. Licitra, G.; Hernandez, T. M.; Van Soest, P. J.; 1996. Standardization of procedures for nitrogen fractionation of ruminant feeds. In Animal Feed Science and Technology. 57: 347-358.

13. McDonald, P.; Henderson, A. R.; Heron, S. J. 1991. The biochemistry of silage, $2^{\text {nd }}$ ed. Marlow. UK. Chalcombe.

14. Mertens, D. R. 2002. Gravimetric determination of amylase treated neutral detergent fiber in feeds with refluxing in beaker or crucibles: collaborative study. In Journal of AOAC International. 85: $1217-1240$.

15. Nascimento, T. V. C.; de Carvalho, G. G. P.; de Freitas Júnior, J. E.; de Souza, W. F. 2016. Volumosos tratados com aditivos químicos: valor nutritivo e desempenho de ruminantes. In Archivos de Zootecnia. 65: 593-604.

16. Nascimento, T. V. C.; Bezerra, L. R.; Menezes, D. R.; Lucena, A. R. F.; Queiroz, M. A. A.; Trajano, J. S.; Oliveira, R. L. 2017. Condensed tannin-amended cassava silage: fermentation characteristics, degradation kinetics and in-vitro gas production with rumen liquor. In Journal of Agricultural Science. 156: 83-91.

17. Neumann, M.; Oliboni, R.; Oliveira, R. M.; Faria, M. V.; Ueno, R. K.; Reinerh, L. L.; Durman, T. 2010. Aditivos químicos utilizados em silagens. In Pesquisa aplicada \& Agrotecnologia. 3: 187-195.

18. Pahlow, G.; Muck, R. E.; Driehuis, F.; Oude Elferink, J. S. J. W. H.; Spoelstra, S. F. 2003. Microbiology of ensiling. In Buxton, D. R.; Muck, R. E.; Harrison, J. H. (eds.). Silage science and technology. p. 31-93. Madison. USA: American Society of Agronomy. 
19. Pinto, A. P.; Mizubuti, I. Y.; Ribeiro, E. L. A. R.; Pereira, E. S.; Bumbieris Jr., V. H.; Pimentel, P. G.; Salmazo, R.; Carneiro, M. S. S. 2012. Avaliações das silagens de bagaço de laranja e de milho com diferentes aditivos proteicos. In Semina: Ciências Agrárias. 33: 3305-3314.

20. Rebora, C.; Ibarguren, L.; Barros, A.; Bertona, A.; Antonini, C.; Arenas, F.; Calderón, M.; Guerrero, D. 2018. Corn silage production in the northern oasis of Mendoza, Argentina. Revista de la Facultad de Ciencias Agrarias. Universidad Nacional de Cuyo. Mendoza. Argentina. 50(2): 369-375.

21. SAS Institute 2001. User's guide: statistics, Version 8.2. Cary. NC: SAS Institute Inc.

22. Spoelstra, S. F.; Courtin, M. G.; Van Beers, J. A. C. 1988. Acetic acid bacteria can initiate aerobic deterioration of whole crop maize silage. In The Journal of Agricultural Science. 111: 127-132.

23. StatSoft 2004. Statistica: data analysis software system, version 10. http://www.statsoft.com (accessed November 2018).

24. Storm, I. M. L. D.; Kristensen, N. B.; Raun, B. M. L. 2010. Dynamics on the microbiology of maize silage during whole-season storage. In Journal of Applied Microbiology. 109: 1017-1026.

25. Taylor, C. C.; Kung Jr., L. 2002. The effect of Lactobacillus buchneri 40788 on the fermentation and aerobic stability of high moisture corn in laboratory silos. In Journal of Dairy Science. 85: 1526-1532.

26. Vandersluis, B.; Hess, D. C.; Pesyna, C.; Krumhol, E. W.; Syed, T.; Szappanos, R.; Nislow, C.; Papp, B.; Troyanskaya, O. G.; Myers, C. L.; Caudy, A. A. 2014. Broad metabolic sensitivity profiling of a prototrophic yeast deletion collection. In Genome Biology. 15: 1-18.

27. Vieira, D. A.; Cezário, A. S.; Valente, T. N. P.; Ribeiro, J. C.; Santos, W. B. R.; Ferreira, P. R. N. 2017. Evaluation of the addition of urea or calcium oxide $(\mathrm{CaO})$ on the recovery of dry matter of the by-product of sweet corn silage. In The Journal of Agricultural science. 9: 141-148.

28. Weinberg, Z. G.; Khanal, P.; Yildiz, C.; Chen, Y.; Arieli, A. 2011. Ensiling fermentation products and aerobic stability of corn and sorghum silages. In Grassland Science. 57: 46-50.

29. Zanine, A. M.; Bonelli, E. A.; Souza, A. L.; Ferreira, D. J.; Santos, E. M.; Pinho, R. M. A.; Parente, H. N.; Parente, M. O. M. 2018. Fermentation and chemical composition of guinea grass silage added with wheat meal and Streptococcus bovis. In New Zealand Journal of Agricultural Research. 45: 1-8.

30. Zanine, A. M.; Santos, E. M.; Dorea, J. R. R.; Dantas, P. A. S.; Silva, T. C.; Pereira, O. G. 2010. Evaluation of elephant grass with addition of cassava scrapings. In Revista Brasileira de Zootecnia. 39: 2611-2616.

\section{ACKNOWLEDGMENTS}

The authors wish to thank the Fundação de Amparo à Pesquisa e ao Desenvolvimento Científico e Tecnológico do Maranhão (FAPEMA) and Coordenação de Aperfeiçoamento de Pessoal de Nível Superior (CAPES) for financial support. 